\title{
Studies on the mosquitoes in the Yaeyama Islands, Japan* \\ 7. Observations on the mating behavior of Aedes (Verrallina) iriomotensis
}

\author{
Ichiro Mryagi** and Takako TomA** \\ Laboratory of Medical Zoology', School of Health Sciences, Faculty of Medicine, \\ University of the Ryukyus, Naha, Okinawa 902, Japan
}

(Received: May 30, 1981)

\begin{abstract}
Specialized mating behaviors of Aedes (Verrallina) iriomotensis Tanaka and Mizusawa, 1973, an indigenous species of the Ryukyu Is., are described and photographed. The antennae of the male Ae. iriomotensis are only slightly more plumose than those of the female. The males do not swarm and remain for much time in the vicinity of the breeding sites and meet young females by chance through random flight. Mating excitement of the male seems to be increased rapidly when his legs touch the young virgin female, and copulation usually occurs immediately after emergence of the female on the water surface. Although we have never confirmed the presence of a sex attractant in this species, our observations suggest that a volatile female sex pheromone might play a somewhat important role in successful mating of this species.
\end{abstract}

In the course of rearing $A e$. iriomotensis collected from Iriomotejima, Ryukyu Is., Japan, we observed several unusual mating habits of this mosquito, one of which is that the male sometimes stay on the head of an emerged female and then copulates with her on the water surface (Miyagi and Toma, 1979, 1980, 1981). This publication presents the results of detailed observations of the mating behavior and bionomics of Ae. iriomotensis in the laboratory and the field.

\section{Materials and Methods}

The Ae. iriomotensis used in this study was obtained from the laboratory colony main-

* This work was supported in part by the grant for the scientific research 1980 (C, No. 547118) from the Ministry of Education, Science and Gulture of Japan.

**宮城一郎, 当間孝子: 琉球大学医学部保健学科保 健生物学教室（干 902 沖繩祡那羁市与儀 1 丁目 3 番 1 号) tained since 1978 from the material collected in Iriomotejima by us (Miyagi and Toma, 1981). Experimental mosquitoes were kept in an air-conditioned insectary in which the temperature was approximately $26^{\circ} \mathrm{C}$ and the relative humidity was 70 to $80 \%$. A photoperiod of $16 \mathrm{hr}$ of daylight was provided by fluorescent tubes. Rearing methods were generally similar to those described by Miyagi and Toma (1981). Observations on mating behavior were made several times with approximately 2,000 immature larvae and pupae in a shallow plastic tray $(40 \times$ $40 \times 8 \mathrm{~cm}$ ) holding about $1,000 \mathrm{ml}$ tap water, pebbles and reeds, all of which were placed in a screened cage $(60 \times 60 \times 40 \mathrm{~cm})$. To observe mating activities between different species, some 50 larvae and pupae of $A e$. atriisimilis Tanaka and Mizusawa and $A e$. albopictus (Skuse) were reared together with those of $A e$. iriomotensis in the cage. A small glass box was specially designed for close observation and photography. During a mosquito survey in Iriomotejima from 1975 
to 1979 , the bionomics of the species were observed in the field.

\section{Orservations}

\section{Mating behavior in the rearing cage}

The newly emerged males remain for several hours among the reeds or on the wet pebbles of the margin of the tray; the males usually begin to seek the females for copulation at about $9 \mathrm{hr}$ after emergence. The time required for $180^{\circ}$ rotation of the male terminalia is variable; it is generally rapid and 10 to $15 \mathrm{hr}$ are required for completion. The mature males fly over the surface of the water and search for newly emerged females.

As shown in the photographs, the male stands on or near the emerging female, touching her with his antennae and forelegs (Figs. 2, 3). As soon as the female emerges from the pupal skin, the young virgin female is ready to accept the male; the male faces the female and then rapidly positions himself upsidedown beneath her abdomen (Fig. 4). Copulation then occurs end-to-end, with the male and female facing opposite directions (Fig. 5). The mated pair remains quietly in copula for variable lengths of time, which extend from $4 \mathrm{~min}$ to $3 \mathrm{hr}$ in the 30 instances carefully timed. About 20 to $30 \mathrm{~min}$ after copulation, they usually walk or skate on the water surface and land on a wet pebble or reed in the tray (Fig. 6). The male hangs with the head-downward, suspended solely by his terminalia for minutes and separates from the female. Nearly all the females kept in the cage copulated during the initial $24 \mathrm{hr}$ of maturation and then dispersed to seek a blood-meal. A drop of clear fluid was found on the copula of the male and female, and kept during copulation (Fig. 6). The fluid was drawn out from the female anus and no sperms were detected in the drop by microscopic examination. We often observed that the male sits on the head of an emerging female and guards her from the attack of other males with locomotion by beating his wings. As soon as her emergence is completed, many of the males that skim over her or rest on the pebbles, gather together and struggle or fight over the newly emerged female. The male is unable to recognize the female from a distance, and attempts copulation with emerging males and also with either sex of newly emerged Ae. albopictus and Ae. atriisimilis resting on the water surface. Copulation is successful only with their own females. A virgin female more than 5 days old is receptive and easily copulates with a young male in a small test tube $(1 \mathrm{~cm}$ diameter, $6 \mathrm{~cm}$ long), but in the large cage $(60 \times 60 \times 40$ $\mathrm{cm}$ ) it takes much time to copulate, as they can not recognize each other from distance.

The females are considered to be monogamous; the females almost invariably copulate only once and thereafter repel the males by beating their wings, pushing the males with legs or changing body positions.

\section{Morphological peculiarities in the male}

Morphological peculiarity of $A e$. iriomotensis is found in the male antennae. The male antennae are only slightly more plumose than the female ones (Figs. 7, 8). Flagellomere 12 is 0.35 to 0.40 the length of flagellomere 13 and both together are 0.90 to 0.98 of flagellomeres 1-11. As compared with other mosquitoes aggregated in flying swarms such as Cx. tritaeniorhynchus Giles, the long fibrillae of the first 11 antennal segments of Ae. iriomotensis are somewhat short, and the distal antennal segment (flagellomere 13) is long.

Fig. 1 Emergence of female Ae. iriomotensis in an upright position

Fig. 2 Male Ae. iriomotensis touching an emerging female

Fig. 3 Two males of Ae. iriomotensis fighting over an emerging female

Fig. 4 Upside-down male Ae. iriomotensis attempting copulation with emerging female

Fig. 5 Male (left) and female Ae. iriomotensis in copula on the water surface and another male attempting to copulate with the female

Fig. 6 Male (left) and female Ae. iriomotensis in copula on a wet stone A drop of clear fluid is found on copula of male and female.

Fig. 7 Male antenna of Ae. iriomotensis is only slightly more plumose than the female

Fig. 8 Female antenna of Ae. iriomotensis 

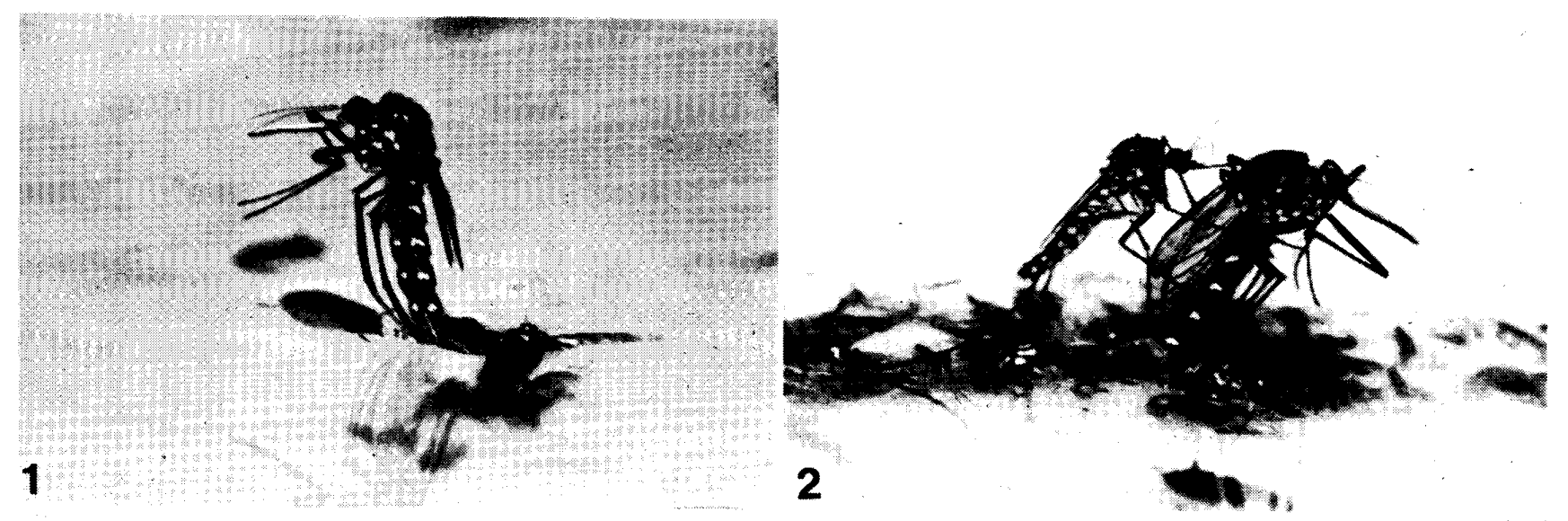

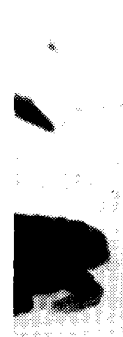

3
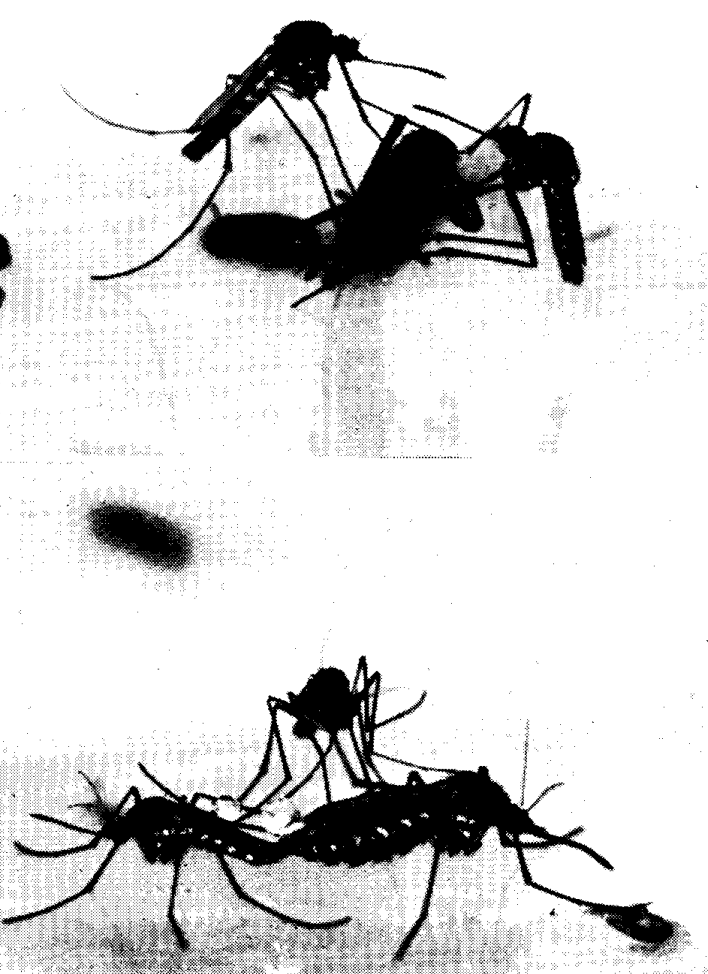

5

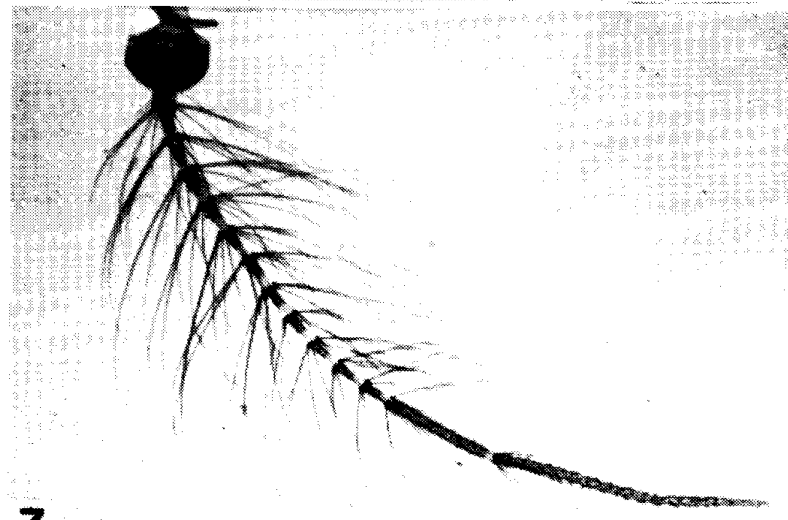

I

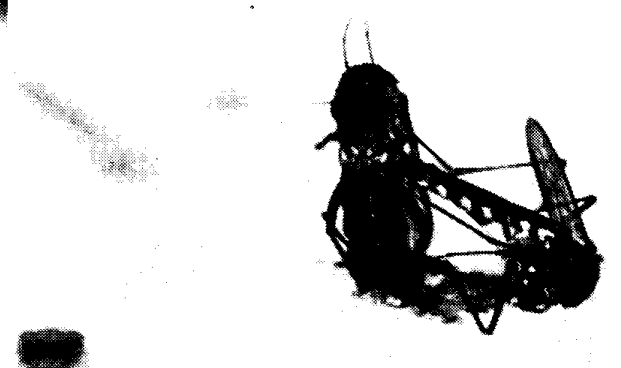

4

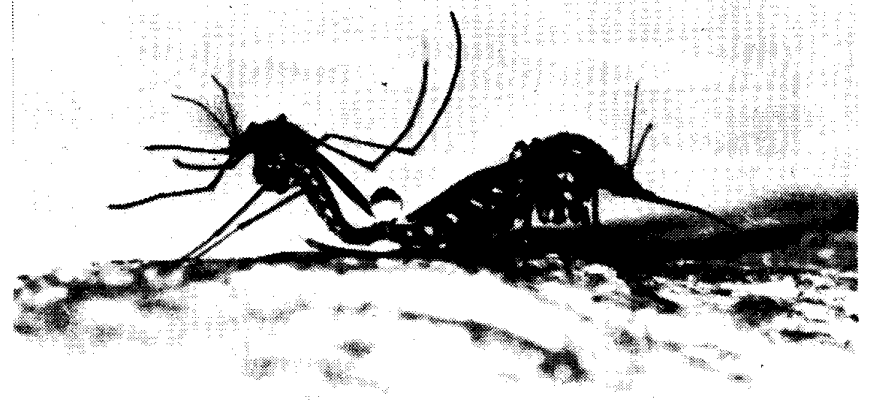

6

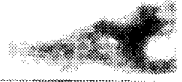

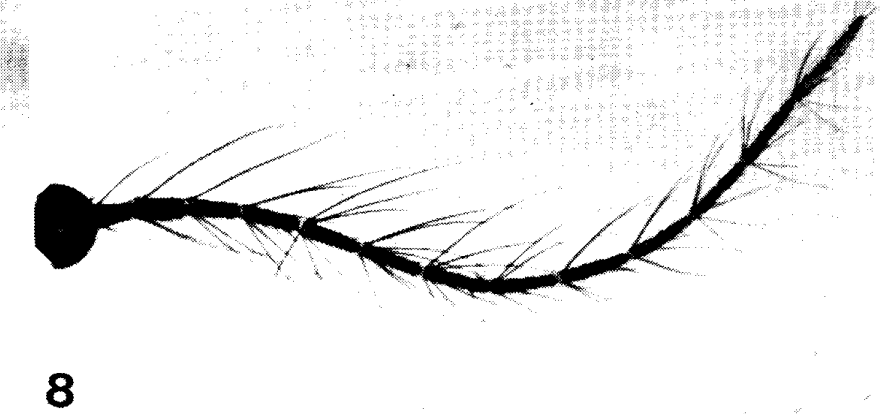

Figs. 1-8 


\section{Field observations}

During the mosquito survey from 1975 to 1979 in Iriomotejima, the following bionomics of $A e$. iriomotensis have been observed.

Ae. iriomotensis is usually the most abundant and vicious day and night time biter in the forest. It is readily collected using a sweeping net around humans. Generally, the females are abundant throughout the year except the winter season from November to February. However female abundance was apparently variable from year to year, and only a few females came to us in March and September 1976. We have never collected males using a sweeping net around humans during the survey. The larvae were quite rare, being rarely encountered in temporary ground pools in the partially or deeply shaded jungle and bamboo forest in Funaura at the end of February 1978 and July 1979. There were many males resting on plants and wet stones of the margin of the breeding pool and they were making exploratory flights on the surface of water. A few pairs of males and females in copula were found on the surface of water and vegetation, but no flying swarms were observed around the breeding place.

\section{Discussion}

The subgenus Verrallina Theobald is restricted primarily to the Oriental zoogeographical region except with a short extension north of Okinawa, Kyushu, Japan and east into Carolin, New Guinea, South Pacific Islands and south into northeastern Australia, and approximately 100 species have been described (Knight and Stone, 1977). Three species of the subgenus, Ae. iriomotensis Tanaka and Mizusawa, Ae. atriisimilis Tanaka and Mizusawa and Ae. nobukonis Yamada, have been recognized in the Ryukyu Is., Japan (Tanaka and Mizusawa, 1973; Tanaka et al., 1979).

Although several species of the subgenus are extremely abundant biting pests and might well be involved in pathogen transmission, the bionomics of the group is very poorly known. The meager information on the bionomics is summarized in Belkin (1962), Huang (1968) and Reinert (1974). How- ever, no information concerning the specialized mating behavior of Verrallina species is found in the literature except for our preliminary observation on Ae. iriomotensis and Ae. atriisimilis (Miyagi and Toma, 1979, 1981).

Mating habits of mosquitoes vary considerably in each species and Nielsen and Haeger (1960) reviewed on swarming and mating in Culicidae. In many species, such as Anopheles philippinensis Ludlow, Aedes taeniorhynchus (Wiedemann), Mansonia perturbans (Walker), Psorophora ferox (Humboldt) and Culex tritaeniorhynchus Giles, mating is more or less associated with swarming (Wharton, 1953; Nielsen and Haeger, 1960; Nielsen, 1964; Kawai et al., 1967). The swarm is first formed by the adult males, and then females are attracted to the sound which these males emit and are seized by one of the males in the swarm; the pair drops out to continue in private on the ground. In many Ae. (Stegomyia) species, like $A e$. aegypti (Linnaeus) and $A e$. albopictus (Skuse), swarming has never been seen although swarm-like flights occur. The sound produced by the females in flight is the external stimulus which attracts the male and induces him to mate in flight (Roth, 1948).

In some species, swarming is not associated with their mating behavior; males remain near the emergence site where they find and mate with newly emerged females. Some examples of mosquitoes having such mating habits are Culiseta inornata (Williston), Opifex fuscus Hutton and some species of Deinocerites (Downes, 1969; Kliever et al., 1966, 1967; McGregor, 1965; Downes, 1966; Provost and Haeger, 1967; Galindo, 1967). The mating behavior of Ae. iriomotensis is rather similar to that of Cs. inornata which was described by Downes (1958) and Lang (1977). The male and female Ae.iriomotensis remain at the emergence site and the male makes repeated short-range flights among the grasses and on the water surface. The male has many chances to meet or touch young females through this random flight. When the male touches the female with his legs, the mating stimulus seems to increase rapidly. In the laboratory, we have often observed that 
once the male touches the young virgin female or emerging female, he remains within a very short distance of the female. As soon as the female emerges from the pupal skin, many males begin a darting flight and struggle over the female. One of the males goes immediately into copulation end to end. The pair remain quietly in copula for about 15 min. During that period many males attack the pair frequently in an attempt to copulate. Another endemic Verrallina species of the Islands, $A e$. atriisimilis breeds in small shallow ground pools in the forest. This species is biologically quite different from Ae. iriomotensis. We observed in the forest that a few males hover in a sunlit spot near a resting man and as soon as the female come to bite man, one of the males dash out and tap the female, using the hind tarsus. Copulation takes place while the female is feeding on man. Observations on the male behavior of $O p$. fuscus by Haeger and Provost (1965), De. cancer by Provost and Haeger (1967) and Downes (1966) suggested that sex attractants may be produced by the female of these species. Kliever et al. (1966), Lang and Foster (1976) and Lang (1977) demonstrated that sex attractant was produced in the male Cs. inornata. We have no information on the sex pheromones of Ae. iriomotensis. However, field and laboratory observaitons on mating behavior of this species suggested that the mating is not only dependent on either sound or sight, but a tactile stimulus is involved in it and further more, certain pheromones might play a relatively important role within a very short distance. A further study is required to reveal if and how the pheromones and tactile stimulus are involved in the mating activity in this mosquito species.

\section{ACKNOWLedgements}

We would like to thank Drs. R. A. Ward and J. F. Reinert who aided us by critically reviewing the first draft of this manuscript. Thanks are due to Drs. O. Suenaga and T. Oda, Nagasaki University, for their gift of copies of references.

\section{REFERENGES}

Belkin, J. N. (1962): The mosquitoes of the
South Pacific (Diptera: Culicidae), Vol. 1, 698 pp., Univ. Calif. Press.

Downes, J. A. (1958): Assembly and mating in the biting Nematocera. Proc. Tenth Int. Congr. Entomol. Montreal, 1956, 2: 425-434.

Downes, J. A. (1966): Observations on the mating behavior of the crab hole mosquito Deinocerites cancer (Diptera: Culicidae). Can. Entomol., 98(11): 1169-1177.

Downes, J. A. (1969): The swarming and mating flight of Diptera. Annu. Rev. Entomol., 14: 271-298.

Galindo, P. (1967): Preliminary observations of the colonization and bionomics of the crab-hole breeding mosquito Deinocerites pseudes Dyar and Knob, 1909. Mosq. News, 27(2): 187-190.

Haeger, J. S. and M. W. Provost (1965): Colonization and biology of Opifex fuscus. Trans. R. Soc. N. Z., 6(3): 21-31.

Huang, Y.-M. (1968): Aedes (Verrallina) of the Papuan subregion (Diptera: Culicidae). Pac. Insects Monogr., 17: 1-73.

Kawai, S., Y. Wada and N. Omori (1967): Preliminary note on the swarming of Culex tritaeniorhynchus. Trop. Med. Nagasaki, 9(1): 58-64.

Kliever, J. W., T. Miura, R. C. Husbands and C. H. Hurts (1966): Sex pheromones and mating behavior of Culiseta inornata (Diptera: Culicidae). Ann. Entomol. Soc. Am., 59(3): 530-533.

Kliever, J. W., B. Rosay, T. Miura, C. M. Myers and M. M. Boreham (1967): Swarming and mating of some California mosquitoes. J. Med. Entomol., 4(4): 490-494.

Knight, K. L. and A. Stone (1977): A catalog of the mosquitoes of the world (Diptera: Culicidae). 2nd ed., Thomas Say Found., Entomol. Soc. Am., 6: 1-611.

Lang, J. T. (1977): Contact sex pheromone in the mosquito Culiceta inornata (Diptera: Culicidae). J. Med. Entomol., 14(4): 448-454.

Lang, J. T. and W. A. Foster (1976): Is there a female sex pheromone in mosquito Culiceta inornata? Enziron. Entomol., 5(6): 1109-1115.

McGregor, D. D. (1965): Aspects of the biology of Opifex fuscus Hutton (Diptera: Culicidae). Proc. R. Entomol. Soc. London (A), 40(1-3): 9-14.

Miyagi, I. and T. Toma (1979): Studies on the mosquitoes in the Yaeyama Islands, Japan. 3. Description of the male, pupa and larva of Aedes (Verrallina) iriomotensis (Diptera: Culicidae). Mosq. Syst., 11(1): 14-25.

Miyagi, I. and T. Toma (1980): Studies on the mosquitoes in the Yaeyama Islands, Japan. 5. Notes on the mosquitoes collected in forest areas 
of Iriomotejima. Jap. J. Sanit. Zool., 31(2): 81-91 (in Japanese, with English summary).

Miyagi, I. and T. Toma (1981): Studies on the mosquitoes in the Yaeyama Islands, Japan. 6. Colonization and bionomics of Aedes (Verrallina) iriomotensis and Aedes (Verrallina) atriisimilis. Mosq. News, $\mathbf{4 1}$, in press.

Nielsen, E. T. (1964): Swarming and some other habits of Mansonia perturbans and Psorophora ferox (Diptera: Culicidae). Behaviour, 24: 67-89.

Nielsen, E. T. and J. S. Haeger (1960): Swarming and mating in mosquitoes. Misc. Publ. Entomol. Soc. Am., 1: 71-95.

Provost, M. W. and J. S. Haeger (1967): Mating and pupal attendance in Deinocerites caner and comparisons with Opifex fuscus (Diptera: Culicidae). Ann. Entomol. Soc. Am., 60(3): 565574.

Reinert, J. F. (1974): A new interpretation of the subgenus Verrallina of the genus Aedes (Diptera: Culicidae). Contrib. Am. Entomol. Inst. (Ann Arbor), 11(1): 1-249.

Roth, L. M. (1948): A study of mosquito behaviour. Experimental study of the sexual behaviour of Aedes aegypti (Linnaeus). $A \mathrm{~m}$. Midl. Nat., 40(2) : 265-352.

Tanaka, K. and K. Mizusawa (1973): Two new species of the genus Aedes (Neomacleaya) from the Ryukyu Islands (Diptera: Culicidae). Bull. Natl. Sci. Mus. Tokyo, 16(4) : 625-638.

Tanaka, K., K. Mizusawa and E. S. Saugstad (1979): A revision of the adult and larval mosquitoes of Japan (including the Ryukyu Archipelago and the Ogasawara Islands) and Korea (Diptera: Culicidae). Contrib. Am. Entomol. Inst. (Ann Arbor), 16: 1-987.
Wharton, R. H. (1953): The habits of adult mosquitoes in Malaya. IV. Swarming of anophelines in nature. Ann. Trop. Med. Parasitol., 47: 285-290.

\section{摘要}

八重山群島の蚊科に関する研究

7. クロフトオヤブカの交尾習性

西表島特産のクロフトオヤブカの特殊化した交尾習 性について主として室内で観察し，連続写真を付して 説明した.

多くの蚊の雄では触角毛は雌に比べて顕著で，交尾 は幼虫時の生息水域から一度分散した後, 雄が再びあ る特定の場所に集合して作る蚊柱（swarm）内で行わ れる場合が多い，クロフトオヤブカの雄の触角毛は踓 よりは毛深いが著しい差はない，雄は蚊柱を作る習性 はなく，幼虫発生水域に羽化後もしばらくとどまり， $7 \sim 10$ 時間後には成熟し，水面すれすれに旋回した。 手あたりしだい水面の浮遊物に触れ，羽化中の雌と接 触すると交尾欲は一層高まり, 旋回は活発になるよう に思われた. 雄は普通羽化直後の水面で静止している 雌の背中に乗り, 直ちに前方に移って逆立ちし, 雌の 体の下側にもぐり込み，雌の体を持ち上げるようにし て下から生殖器を交接した. この雌雄は生殖器を連結 させたまま水面に普通 30 分，長い時は 3 時間静止し た. やがて雔は体が黒色になり成熟すると雄を引きず るようにして水面から岸辺にはい上がった. この間, 旋回寸る別の雄がこのペアーに向かって何回も交尾を 仕掛け，時には水面で数個体の雄が団子のよ5に絡み 付いたが連結は離れなかった. その後, 雌は後肢で雄 をけりつけ, 生殖器の連結は分離し, 交尾は完了し た. 充分交尾した雌は雄を二度と寄せっけなかった。 このよ5な実験室内の一連の交尾行動から判断して本 種の交尾にはある種の性誘引フェロモンが関与してい ると思われるが，今後の研究に待ちたい。 